\title{
RECONNAISSANCE STRATIGRAPHY OF THE RED GLACIER FORMATION (MIDDLE JURASSIC) NEAR HUNGRYMAN CREEK, COOK INLET BASIN, ALASKA
}

\author{
David L. LePain ${ }^{1}$, Richard G. Stanley ${ }^{2}$, and Kenneth P. Helmold ${ }^{3}$
}

\section{INTRODUCTION}

Geochemical data suggest the source of oil in upper Cook Inlet fields is Middle Jurassic organic-rich shales in the Tuxedni Group (Magoon and Anders, 1992; Lillis and Stanley, 2011; LePain and others, 2012, 2013). Of the six formations in the group (Detterman, 1963), the basal Red Glacier Formation is the only unit that includes fine-grained rocks in outcrop that appear to be organic-rich (fig. 3-1). In an effort to better understand the stratigraphy and source-rock potential of the Red Glacier Formation, the Alaska Division of Geological \& Geophysical Surveys, in collaboration with the Alaska Division of Oil and Gas and the U.S. Geological Survey, has been investigating the unit in outcrop between Tuxedni Bay and the type section at Lateral and Red glaciers (Stanley and others, 2013; LePain and Stanley, 2015; Helmold and others, 2016 [this volume]). Fieldwork in 2015 focused on a southeast-trending ridge south of Hungryman Creek, where the lower 60-70 percent of the formation (400-500 m) is exposed and accessible, except for the near-vertical faces of three segments near the southeast end of the ridge (figs. 3-2 and 3-3). Three stratigraphic sections were measured along the ridge to document facies and depositional environments (figs. 3-3 and 3-4). Steep terrain precluded study of the upper part of the formation exposed east of the ridge. This report includes a preliminary summary of findings from the 2015 field season.

\section{RED GLACIER FORMATION NEAR HEADWATERS OF HUNGRYMAN CREEK}

The Red Glacier Formation unconformably overlies the Talkeetna Formation (Horn Mountain Tuff Member) and the contact is relatively well exposed along the ridgetop south of Hungryman Creek. It is tentatively placed at a color change from light brown and gray volcaniclastic sandstones, siltstones, and tuffs in the Horn Mountain to dark brown and red-brown siltstones, sandstones, and conglomerates of the Red Glacier Formation. Sandstones and siltstones above this contact have a characteristic spheroidal weathering pattern not seen in the underlying Talkeetna (fig. 3-5a).

The lower $154 \mathrm{~m}$ of the Red Glacier Formation in section 1 consists of granule and pebble conglomerate, poorly sorted fineto very-coarse-grained sandstone, and minor siltstone (fig. 3-4). Most beds appear structureless but rare, crudely-developed, horizontal stratification is present. Most finer-grained sandstones and siltstones have a mottled appearance suggesting bioturbation, but discrete trace fossils are absent. Shelly macrofossils appear to be absent from the lower $89 \mathrm{~m}$; belemnites, small Inoceramus valves, poorly preserved ammonites, and broken and abraded shell fragments are scattered throughout the remaining part of section 1, but are not abundant (fig. 3-5b). The upper part of section 1 consists of an organized succession of burrow-mottled, very-fine- to fine-grained sandstone with remnant patches of preserved horizontal lamination that grades upsection to medium- to coarse-grained planar(?) and trough cross-bedded sandstone (figs. 3-3, 3-4, and 3-6a).

Facies in the uppermost beds of section 1 and all of sections 2 and 3 record a progradational stack of three coarseningupward shorezone successions (parasequences) (fig. 3-4). The uppermost $10 \mathrm{~m}$ of the lower coarsening-upward succession is accessible at the base of section 2 and consists of interbedded fine-grained, burrow-mottled sandstone and medium- to coarse-grained, planar cross-bedded sandstone in sets up to $80 \mathrm{~cm}$ thick (figs. 3-4 and 3-6b). These sandstones are overlain abruptly by burrow-mottled siltstone above an inferred flooding surface. The upper beds in section 2 include burrow-mottled, fine-grained sandstone with scattered interbeds of fossiliferous fine-grained sandstone (figs. 3-4 and 3-6c) and remnant patches of low-angle inclined laminae in fine-grained sandstone that may represent hummocky cross-stratification; these strata lie near the top of the second coarsening-upward succession (fig. 3-4). Section 3 includes a lower burrow-mottled siltstone above an inferred flooding surface with large pieces of silicified logs (figs. 3-4, 3-7a, and 7-b). Siltstones in section 3 grade up to burrowed, fine-grained sandstone with clams in growth position (fig. 3-7c) and rare ammonites (fig. 3-7d). Approximately $20 \mathrm{~m}$ above section 3, a 5-6-m-thick bed of cobble and boulder(?) conglomerate interrupts the sandstone succession near the top of the third coarsening-upward succession (figs. 3-4 and 3-7a).

\footnotetext{
${ }^{1}$ Alaska Division of Geological \& Geophysical Surveys, 3354 College Rd., Fairbanks, AK 99709-3707; david.lepain@alaska.gov

${ }^{2}$ U.S. Geological Survey, 345 Middlefield Rd., Mail Stop 969, Menlo Park, CA 94025

${ }^{3}$ Alaska Division of Oil and Gas, 550 W. 7th Ave., Suite 800, Anchorage, AK 99501
} 


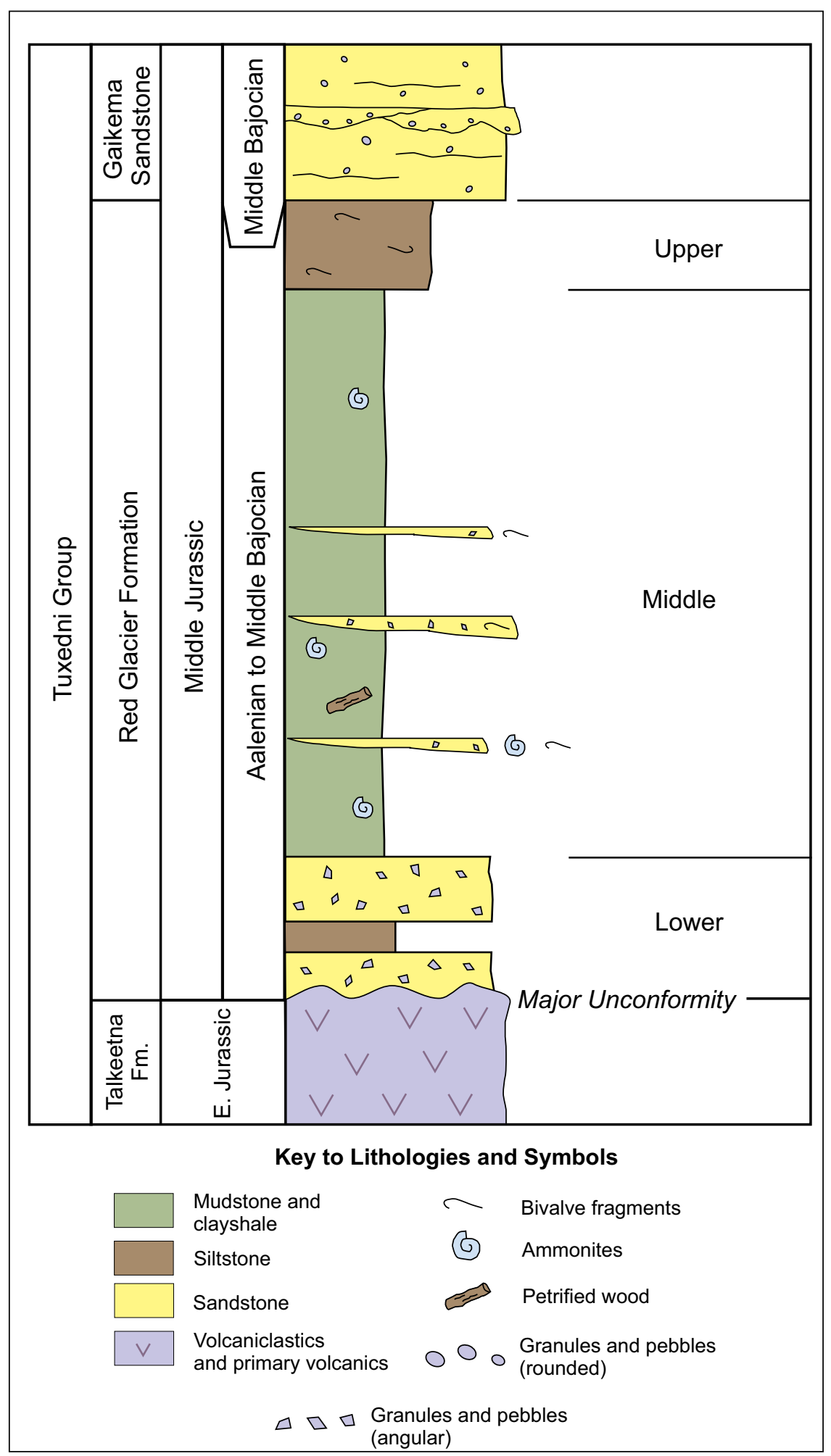

Figure 3-1. Generalized stratigraphic column showing the gross organization of the Red Glacier Formation. Based on fieldwork by the authors at Lateral Glacier in 2014 (LePain and Stanley, 2015). 


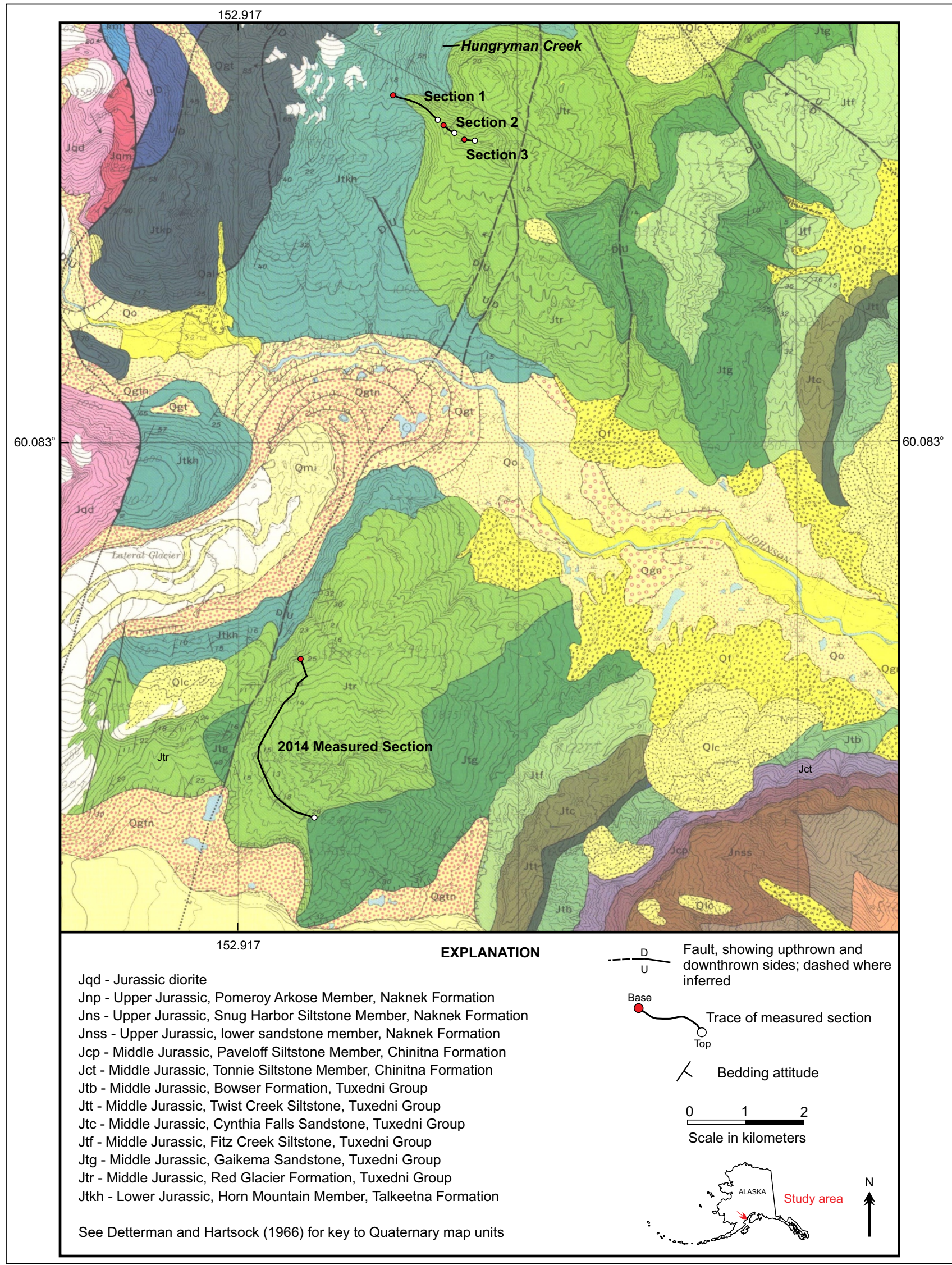

Figure 3-2. Geologic map of the area between Hungryman Creek and Red Glacier (modified from Detterman and Hartsock, 1966). Our 2014 measured section locality is in the type area for the lower part of the Red Glacier Formation. 
The facies progression in the upper part of section 1 and basal beds of section 2 record a progradational delta front or shoreface succession, which is separated by a flooding surface from a similar progradational succession in the remainder of section 2 and immediately above; this stacking motif is repeated in and immediately above section 3 . The conglomerate bed above section 3 records deposition in a shoreline proximal location, but its significance beyond that is unclear; its presence suggests that each successive progradational package records a successively more proximal position in the depositional profile. Helicopter reconnaissance of Red Glacier exposures east of the ridge shows that facies are dominantly coarse grained (siltstone and coarser) up to, and including, the overlying Gaikema Sandstone.

\section{COMPARISON WITH 2014 MEASURED SECTION AT LATERAL GLACIER}

The Red Glacier Formation near Hungryman Creek contrasts sharply with exposures of the formation $9 \mathrm{~km}$ to the south, at Lateral Glacier, where two thick sandstone packages separated by a siltstone interval are present near the base of the formation and are overlain by a 573-m-thick succession of dark brown and black mudstone and fissile clayshale (figs. 3-1, 3-2, and 3-4; LePain and Stanley, 2015). Features in sandstones near the base of the unit at Lateral Glacier suggest deposition from concentrated sediment gravity flows below storm wave base, succeeded by deposition of organic-rich mudstones. Comparable fine-grained facies are absent along the ridgetop near Hungryman Creek. The dramatic difference between the Lateral Glacier and Hungryman Creek successions suggests paleobathymetric control on the distribution of facies; the succession near Hungryman Creek records proximity to a coarse-grained deltaic depocenter while the succession at Lateral Glacier records deposition in an off-axis, distal location in deeper water. Results from the 2014 and 2015 field seasons document facies variations in the Red Glacier Formation along the basin margin that have implications for the distribution of oil-prone source rocks in the subsurface.

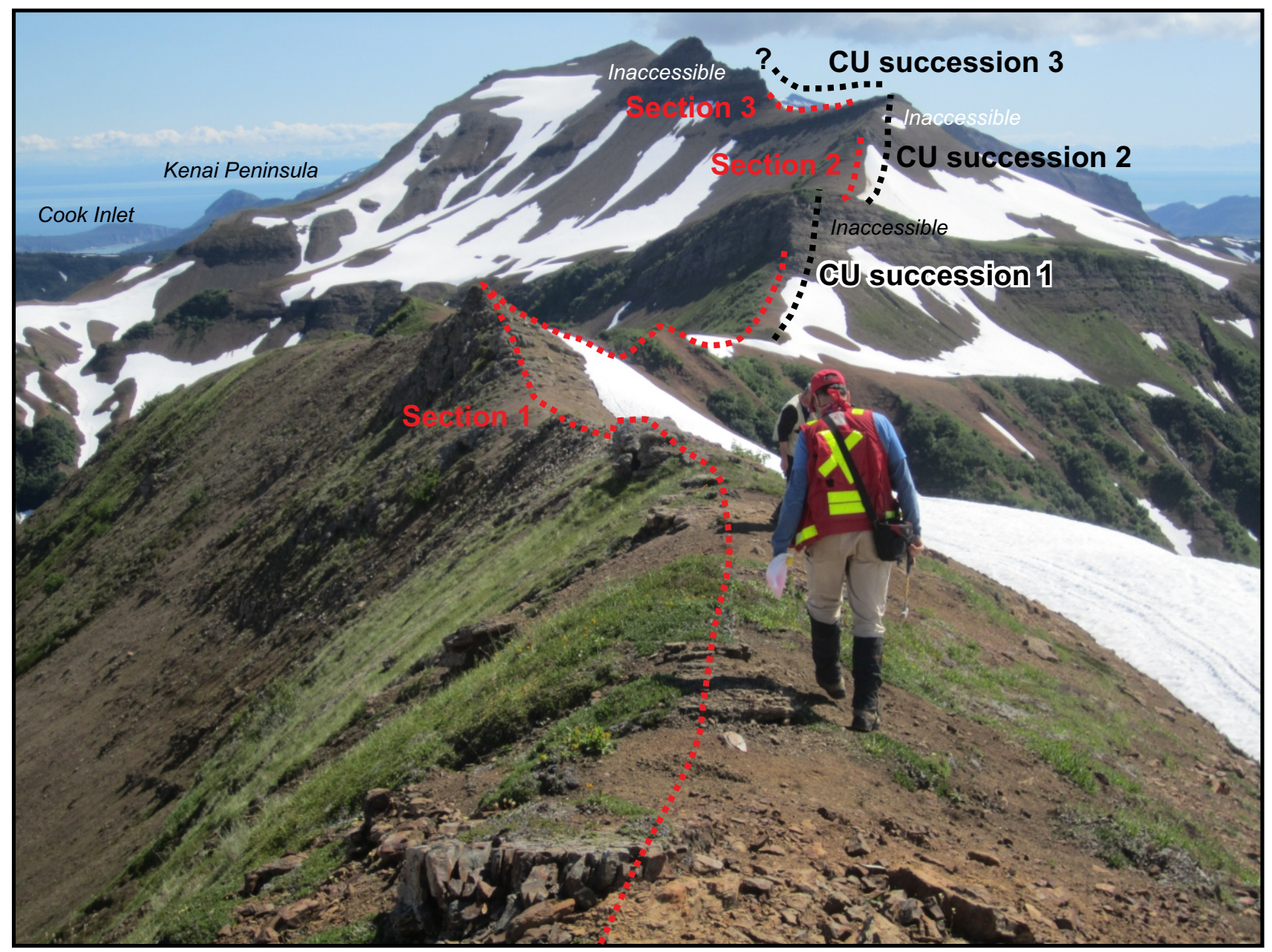

Figure 3-3. Field photograph showing the locations of measured sections 1-3. Note steep, inaccessible slopes separating sections 1 and 2 and sections 2 and 3. The Red Glacier Formation continues above and to the east of section 3, but is inaccessible due to steep topography. $\mathrm{CU}=$ coarsening-upward succession. View is toward the southeast. 


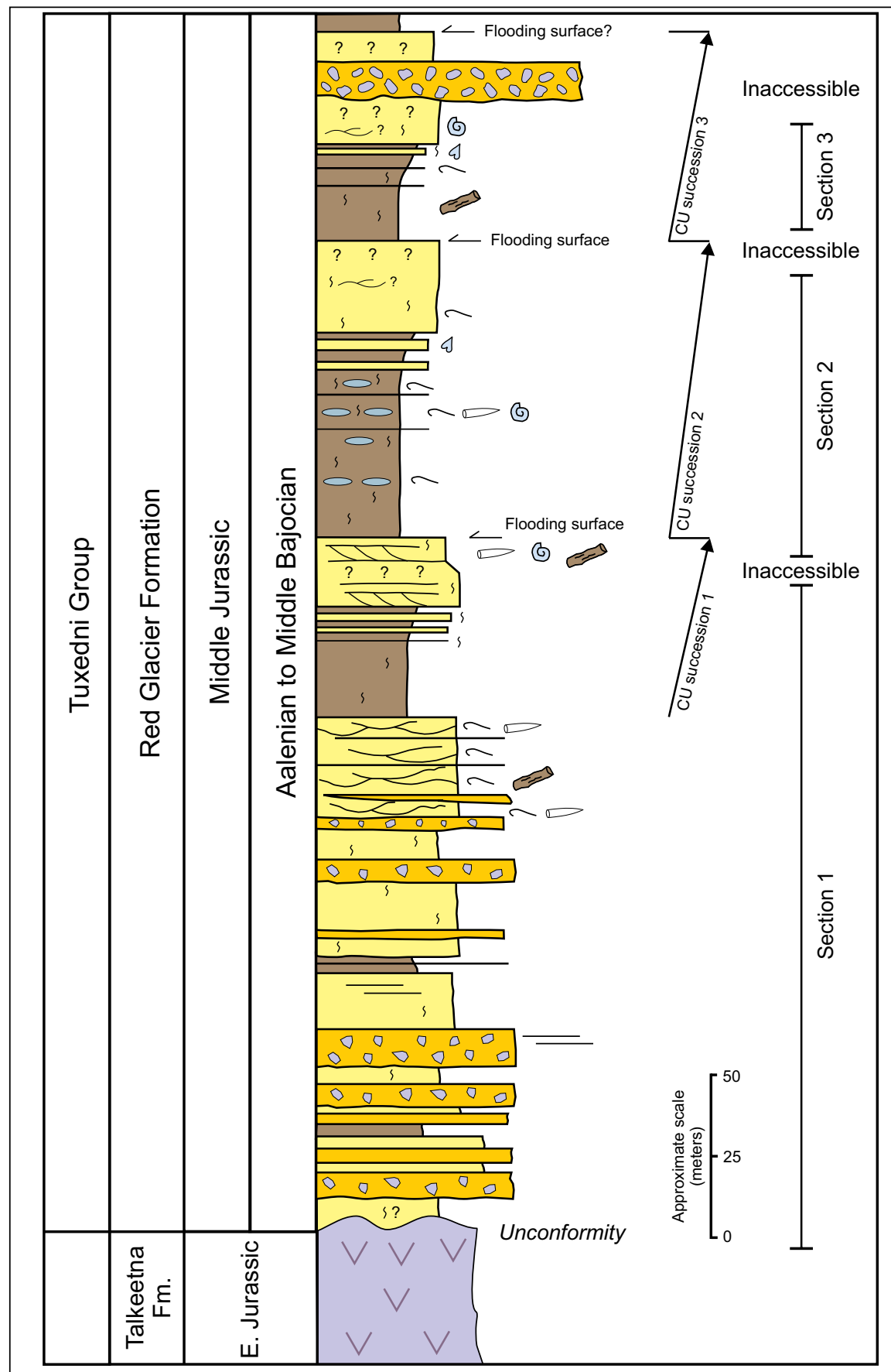

Key to Lithologies and Symbols

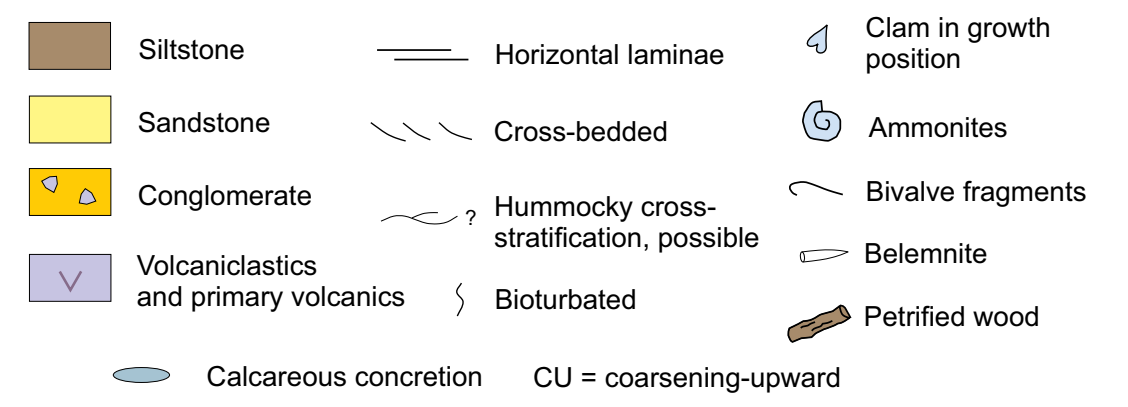

Figure 3-4. Schematic stratigraphic column showing the gross organization of the lower 60-70 percent of the Red Glacier Formation near Hungryman Creek based on fieldwork during the 2015 field season. Each coarsening-upward succession represents a parasequence (Van Wagoner and others, 1990). 


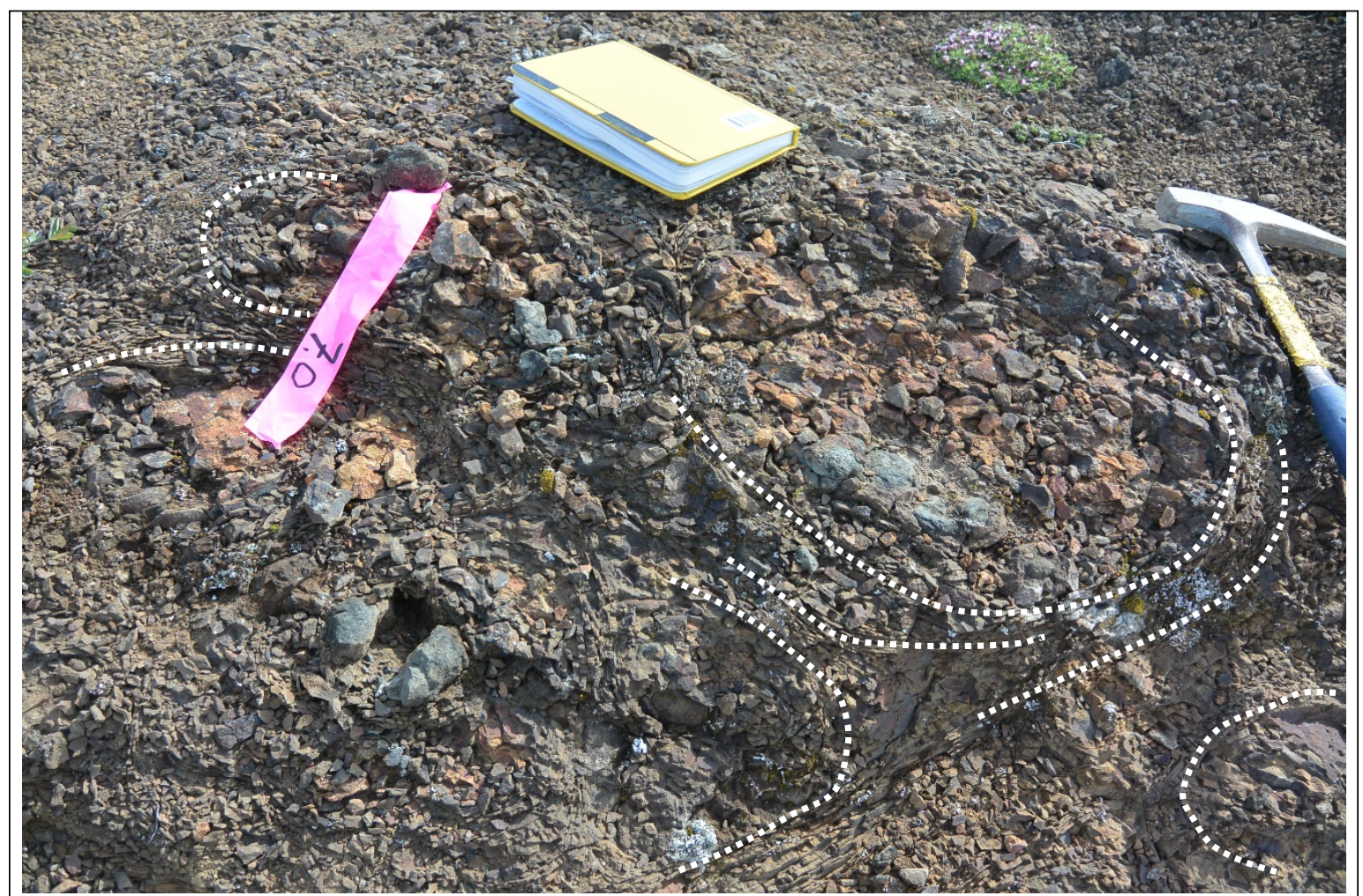

Figure 3-5a

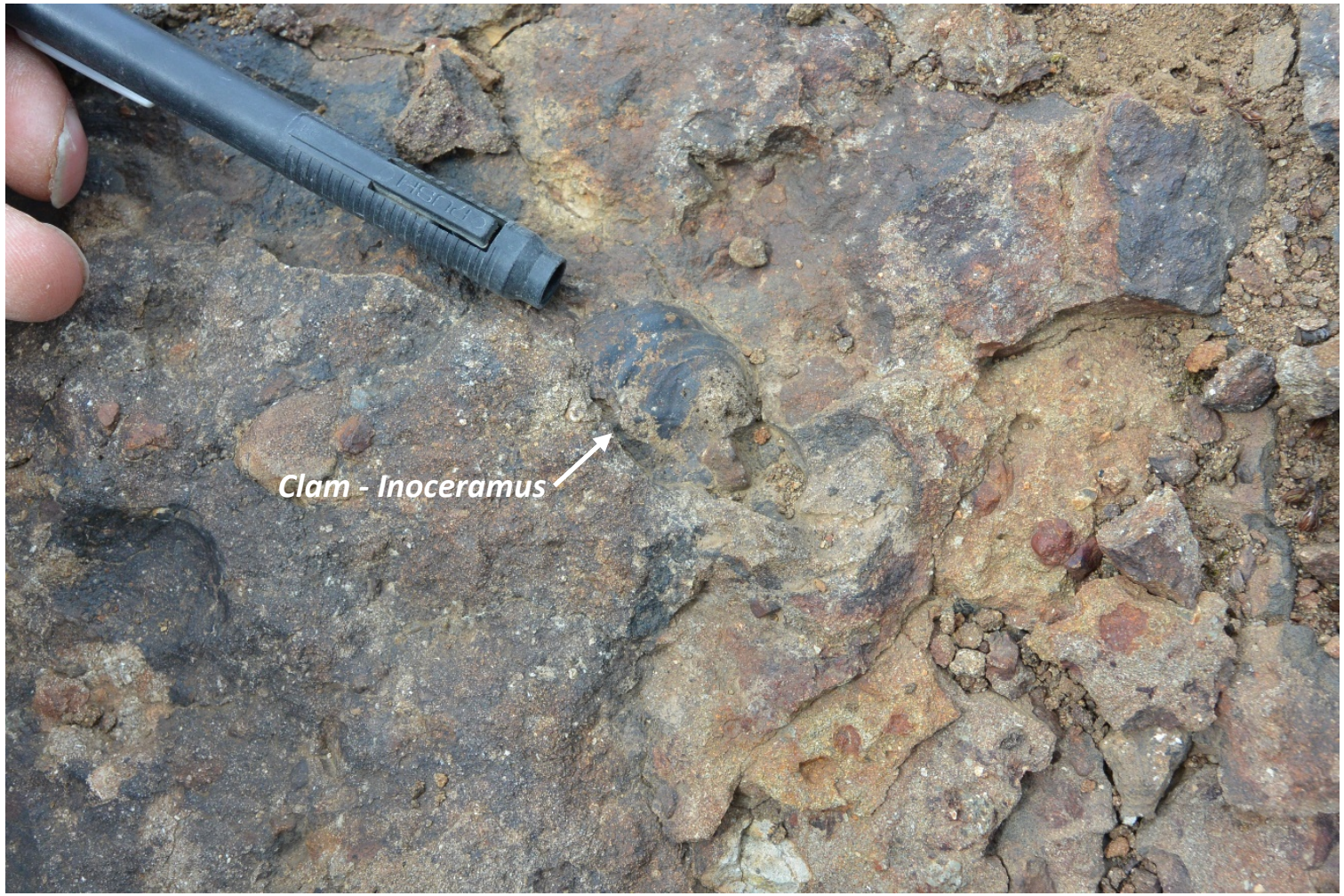

Figure 3-5b

Figure 3-5. Photographs showing features in measured section 1. a. Spheroidal weathering pattern developed in burrowmottled, fine-grained sandstone at $7.0 \mathrm{~m}$ in section 1. Black and yellow bars on notebook are each $5 \mathrm{~cm}$ long. $\boldsymbol{b}$. Cast of moderately-well-preserved clam, Inoceramus, at $91.5 \mathrm{~m}$ in section 1 . Visible part of gray eraser is $7 \mathrm{~cm}$ long. 


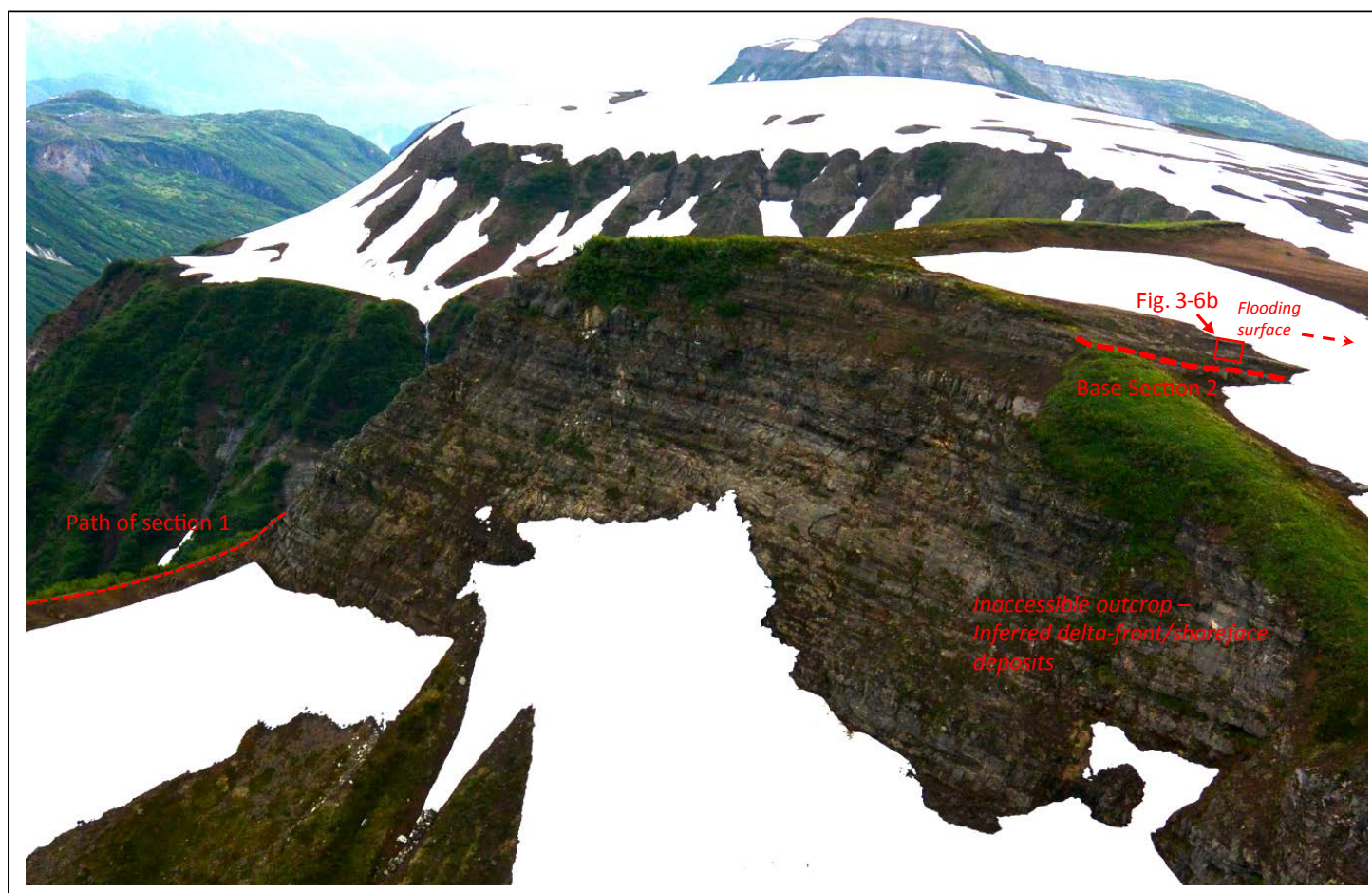

Figure 3-6a

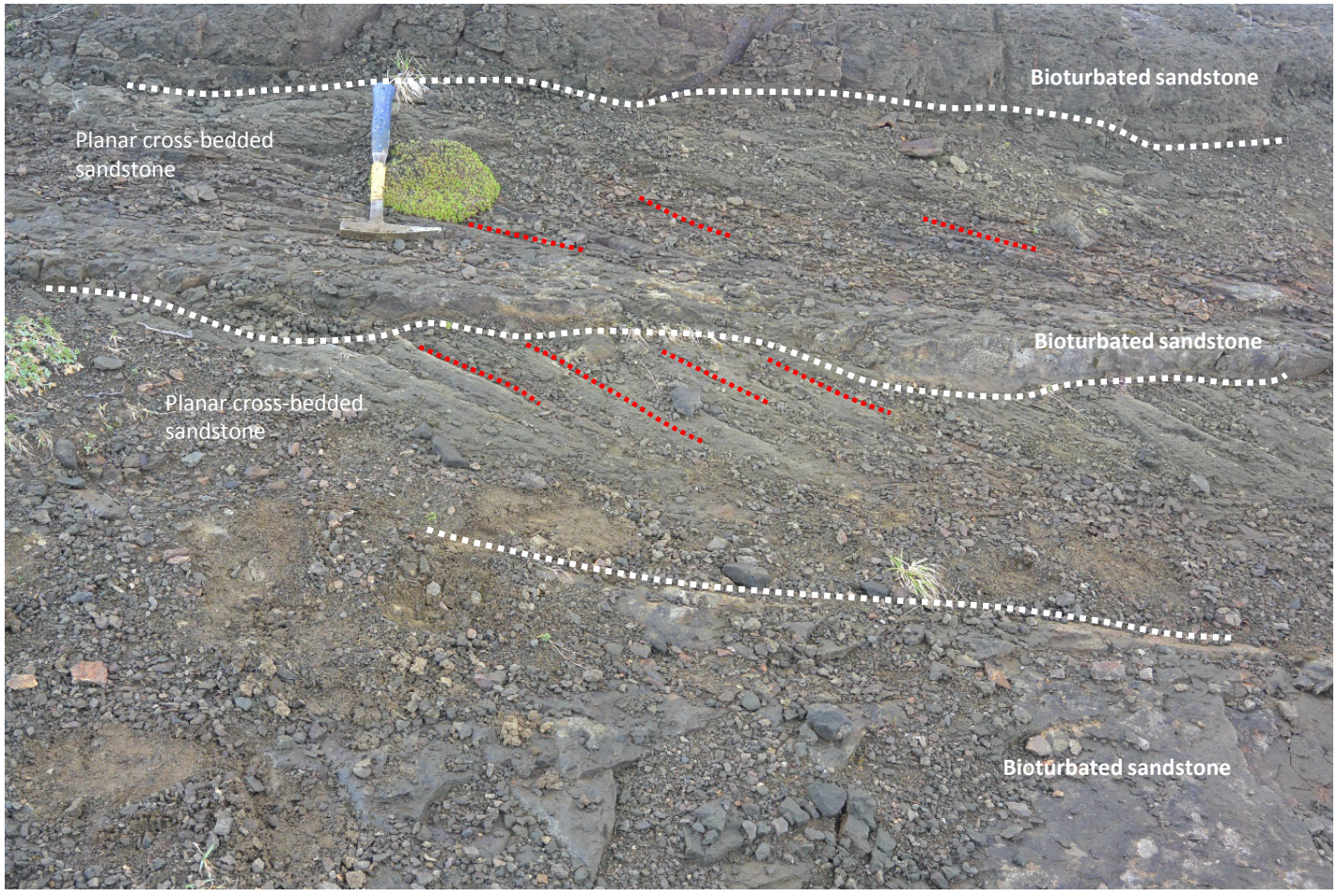

Figure 3-6b

Figure 3-6. Photographs showing features in measured sections 1 and 2. a. Aerial view toward the north showing the upper part of section 1 and base of section 2 with an inaccessible slope separating them. The snow patch above the base of section 2 overlies burrow-mottled siltstone, which is also visible above the snow. A marine flooding surface is concealed beneath the snow patch but is exposed beyond it to the right of the field of view (red arrow) at $10.2 \mathrm{~m}$ in section 2. Red rectangle shows approximate location of photograph in figure 3-6b. Inaccessible section is thought to be 30-40 m thick. $\boldsymbol{b}$. Two sets of planar cross-bedded sandstone separated by bioturbated sandstone. The dashed line immediately above the hammer handle is at $4.2 \mathrm{~m}$ in section 2. Rock hammer is $42 \mathrm{~cm}$ long. The lower $10.2 \mathrm{~m}$ of section 2 comprises the uppermost beds of the lower progradational delta-front/shoreface succession discussed in the text. 


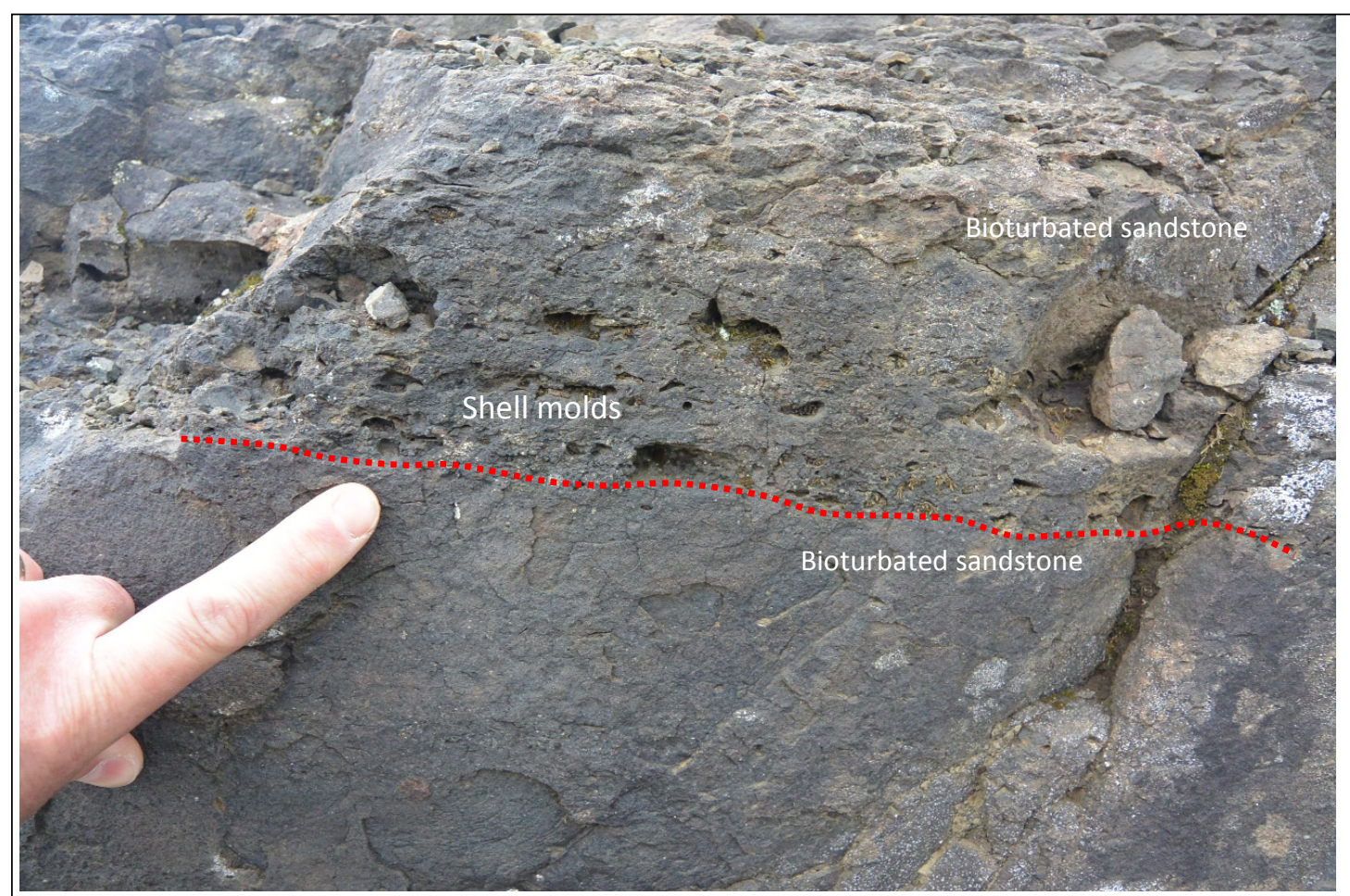

Figure 3-6c

Figure 3-6 (cont.). Photographs showing features in measured sections 1 and 2. c. Fossiliferous sandstone (above finger) separated from bioturbated sandstone (below) by erosion surface (dotted red line). Most voids visible in the fossiliferous sandstone represent shell molds. Bioturbated sandstone overlies the fossiliferous sandstone. 


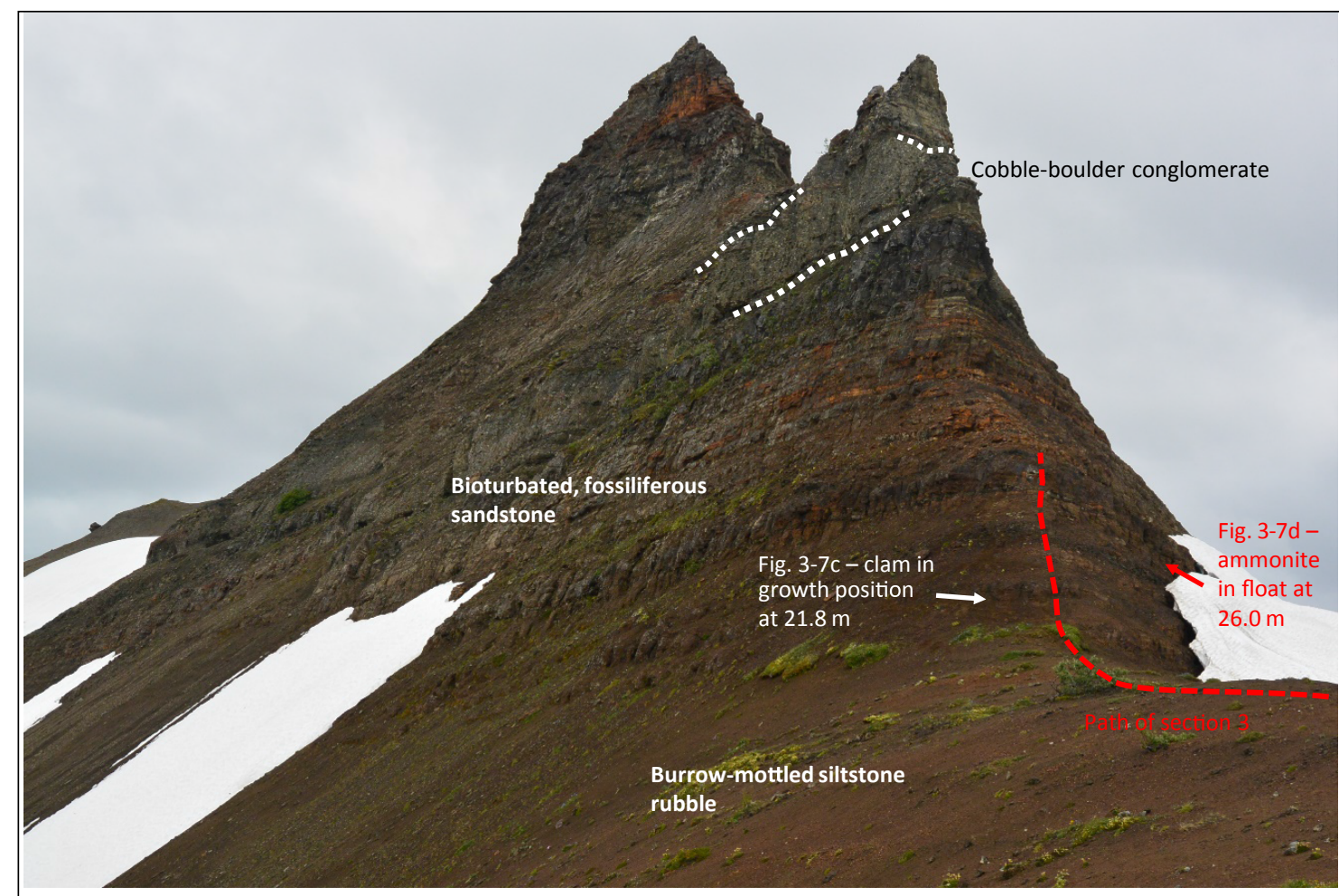

Figure $3-7 a$

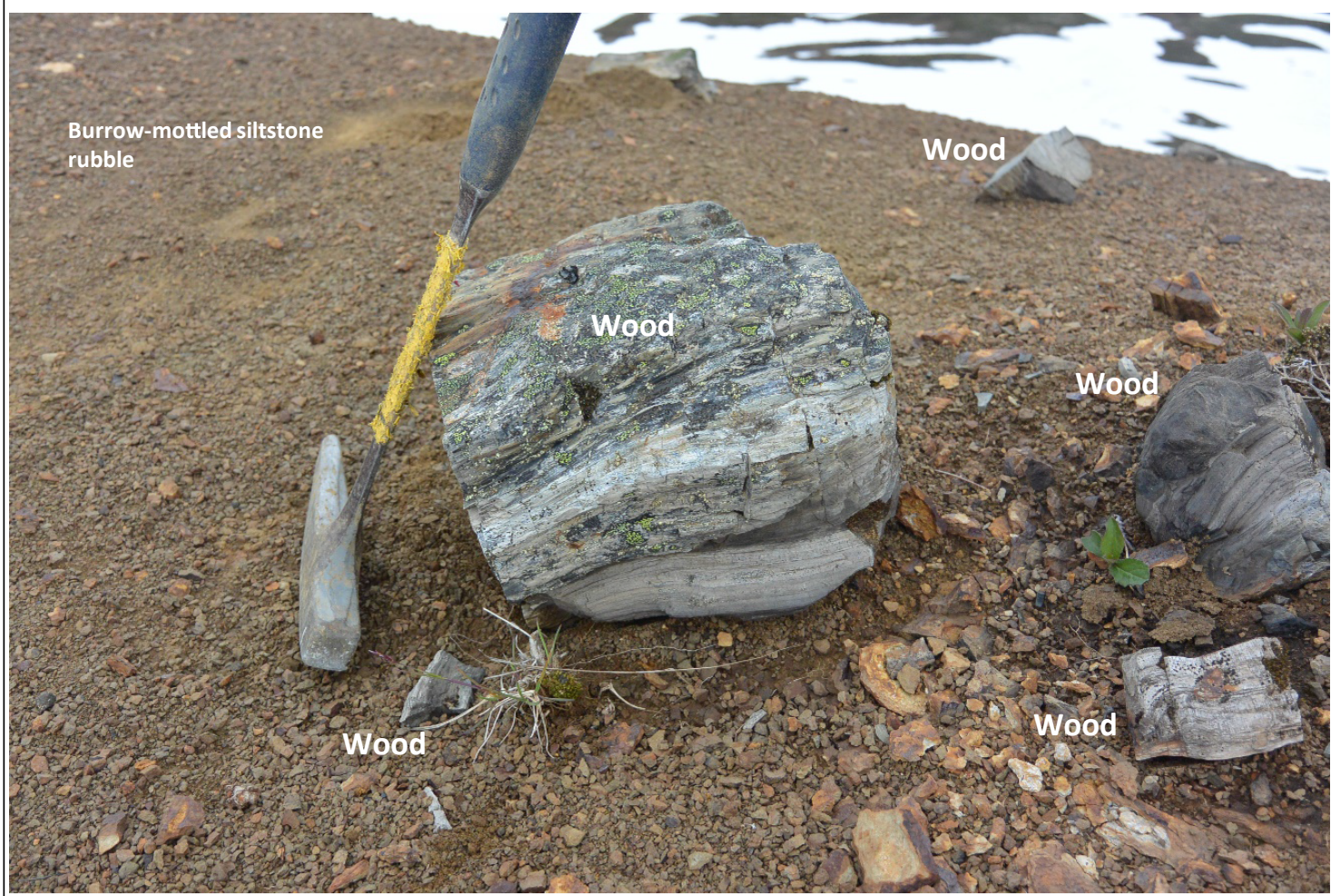

Figure $3-7 b$

Figure 3-7. Photographs showing features in measured section 3. a. Photograph showing the upper part of section 3 and the inaccessible beds above it. Note the cobble-boulder(?) conglomerate approximately $20 \mathrm{~m}$ above the top of section 3. b. Silicified wood fragments weathering out of burrow-mottled coarse siltstone at $15.0 \mathrm{~m}$ in section 3 . Wood was likely transported to the depositional site by flows discharging from a nearby delta distributary channel. Visible part of rock hammer is $30 \mathrm{~cm}$ long. 


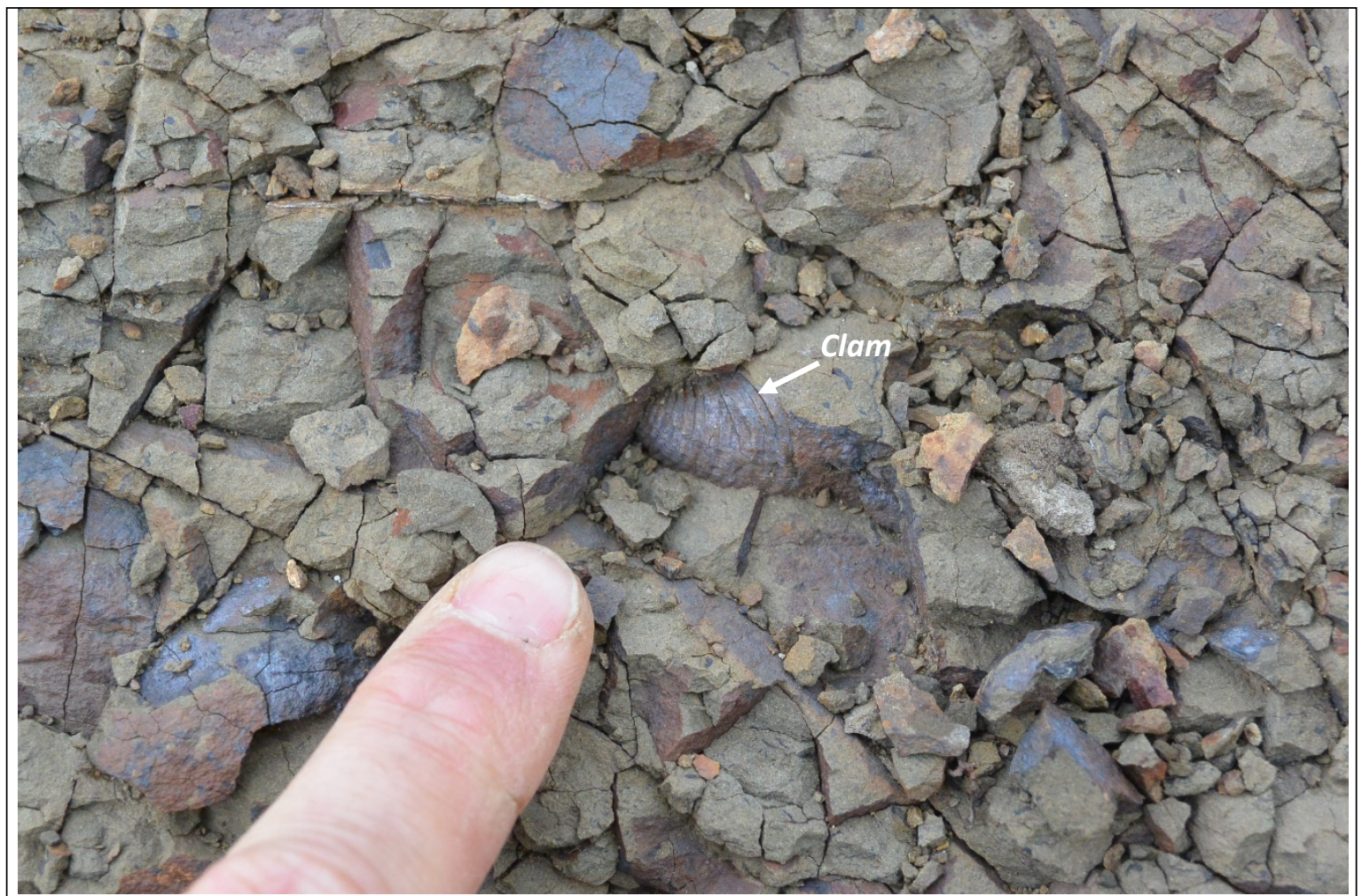

Figure 3-7c

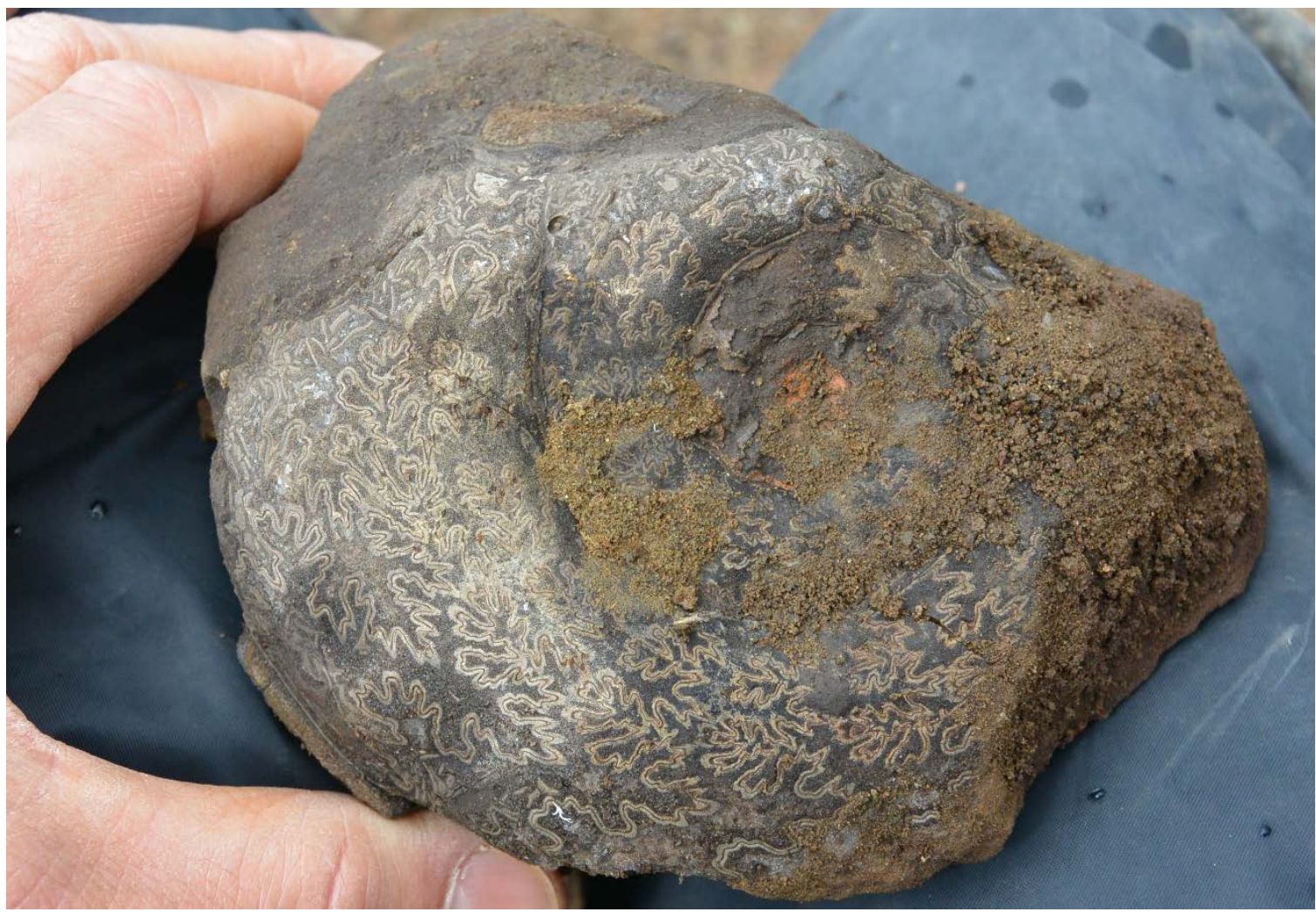

Figure 3-7d

Figure 3-7. Photographs showing features in measured section 3. c. Clam in growth position in bioturbated, very fine sandstone at $21.8 \mathrm{~m}$ in section 3. . Ammonite with well-preserved sutures in float at $26.0 \mathrm{~m}$ in section 3. 


\section{ACKNOWLEDGMENTS}

Funding for the Alaska Department of Natural Resources (DNR) Cook Inlet basin analysis program was provided by the State of Alaska, with additional support from Apache Corporation and the U.S. Geological Survey's National Cooperative Geologic Mapping Program (STATEMAP awards G13AC00157 and G15AC00199). We gratefully acknowledge the following organizations for granting land access: Lake Clark National Park \& Preserve; Cook Inlet Region, Inc.; and Chickaloon, Knik, Ninilchik, Salamatof, Seldovia, and Tyonek Native village corporations. Merlin "Spanky" Handley (Pathfinder Aviation) provided helicopter transportation for the DNR field crew during the 2015 season. We thank the owners and staff of the Snug Harbor Wilderness Lodge on Chisik Island for their hospitality and the DNR Red Glacier-Iliamna bedrock mapping crew for valuable discussions in the field. We thank Trystan Herriott and Nina Harun for their thorough technical reviews of the manuscript.

\section{REFERENCES CITED}

Detterman, R.L., 1963, Revised stratigraphic nomenclature and age of the Tuxedni Group in the Cook Inlet region, Alaska, in U.S. Geological Survey, Geological Survey Research 1963, Short Papers in Geology and Hydrology, Articles 60-121: U.S. Geological Survey Professional Paper 475-C, p. C30-C34.

Detterman, R.L., and Hartsock, J.K., 1966, Geology of the Iniskin-Tuxedni Region, Alaska: U.S. Geological Survey Professional Paper 512, 78 p., 6 sheets, scale 1:63,360.

Helmold, K.P., LePain, D.L., and Stanley, R.G., 2016 (this volume), Sedimentary petrology and reservoir quality of the Red Glacier Formation (Middle Jurassic), Cook Inlet basin-Initial Impressions, in Herriott, T.M., ed., Petroleum-related geologic studies in lower Cook Inlet during 2015, Iniskin-Tuxedni region, south-central Alaska: Alaska Division of Geological \& Geophysical Surveys, Preliminary Interpretive Report 2016-1, p. 33-37, doi:10.14509/29537

LePain, D.L., and Stanley, R.G., 2015, Stratigraphic reconnaissance of the Middle Jurassic Red Glacier Formation, Tuxedni Group, at Red Glacier, Cook Inlet, Alaska, in Wartes, M.A., ed., Energy-related studies during the 2014 field season, western Cook Inlet, Alaska: Alaska Division of Geological \& Geophysical Surveys Preliminary Interpretive Report 2015-5-5, p. 23-28. doi:10.14509/29460

LePain, D.L., Lillis, P.G., Helmold, K.P., and Stanley, R.G., 2012, Migrated hydrocarbons in exposure of Maastrichtian nonmarine strata near Saddle Mountain, lower Cook Inlet, Alaska: Alaska Division of Geological \& Geophysical Surveys Report of Investigation 2012-1, 13 p. doi:10.14509/23943

LePain, D.L., Stanley, R.G., Helmold, K.P., and Shellenbaum, D.P., 2013, Geologic framework and petroleum systems of Cook Inlet basin, south-central, Alaska, in Stone, D.M., and Hite, D.M., eds., Oil and Gas Fields of the Cook Inlet basin, Alaska: AAPG Memoir 104, p. 37-116.

Lillis, P.G., and Stanley, R.G., 2011, Petroleum generation modeling for Cook Inlet basin, Alaska [abs.]: American Association of Petroleum Geologists, Pacific Section Annual Meeting, p. 72.

Magoon, L.B., and Anders, D.E., 1992, Oil-to-source-rock correlation using carbon-isotopic data and biological marker compounds, Cook Inlet, Alaska Peninsula, Alaska, in Moldowan, J.M., Albrecht, Pierre, and Philp, R.P., eds., Biological markers in sediments and petroleum: Englewood Cliffs, N.J., Prentice-Hall, p. 241-274.

Stanley, R.G., Herriott, T.M., LePain, D.L., Helmold, K.P., and Peterson, C.S., 2013, Reconnaissance studies of potential petroleum source rocks in the Middle Jurassic Tuxedni Group near Red Glacier, eastern slope of Iliamna Volcano, in Gillis, R.J., ed., Overview of 2012 field studies - Upper Alaska Peninsula and west side of lower Cook Inlet, Alaska: Alaska Division of Geological \& Geophysical Surveys Preliminary Interpretive Report 2013-1B, p. 5-9. doi:10.14509/24845

Van Wagoner, J.C., Mitchum, R.M., Campion, K.M., and Rahmanian, V.D., 1990, Siliciclastic sequence stratigraphy in well logs, cores, and outcrops: AAPG Methods in Exploration Series, No. 7, 55 p. 